\title{
Effect of Turmeric Supplementation on Production Performance of Adult Laying Birds
}

\author{
Shweta Singh Chauhan ${ }^{*}$, D.D. Caeser ${ }^{2}$, J. Shakkarpude ${ }^{2}$, Kush Shrivastava ${ }^{3}$, \\ Mendi Ali khan ${ }^{2}$ and Aditya Mishra ${ }^{2}$
}

${ }^{1}$ Department of Veterinary Biochemistry, ${ }^{2}$ Department of Veterinary Biochemistry \& Physiology, College of Veterinary Science \& A.H., NDVSU, Jabalpur, M.P., India ${ }^{3}$ Division of Animal Genetics, ICAR- IVRI, Izatnagar, Bareilly, U.P., India

*Corresponding author

\section{A B S T R A C T}

This experiment was conducted to investigate the dietary effects of turmeric powder on production performances like feed intake, body weight, egg weight and egg production. A

\section{Keywords}

Layer, Feed additive, Turmeric, Jabalpur colour, Egg production

Article Info

Accepted:

06 July 2018

Available Online:

10 August 2018 total of thirty, 32-wk-old, Jabalpur colour layers were divided into five groups six layers in each, and fed each one of five diets containing $0 \%$ turmeric powder (control), 1.5, 3.0, 4.5 and $6.0 \mathrm{~g}$ of turmeric powder $/ \mathrm{kg}$ feed for treatment groups T1-T4, respectively, for $8 \mathrm{wks}$. No differences in feed intakes, egg weight and eggshell qualities were observed among the treatments, but production in the groups fed with diets containing turmeric powder was significantly higher than that in control $(\mathrm{P}<0.05)$, the maximum increase $(53.60 \%)$ in egg production was observed in groups T2 and T3 on day 56 of experiment. Significant body weight gain of $10.44 \%$ was observed in treatment group T3 fed diet containing turmeric powder supplementation $4.5 \mathrm{~g} / \mathrm{kg}$ feed. The cholesterol levels of egg yolk were significantly influenced by dietary turmeric supplementation. It was concluded that dietary turmeric supplementation was effective in improving laying performance and internal egg qualities. Turmeric powder can be also used as a feed additive for the production of valueenhanced eggs production with increased body weight hence reducing cost of feed for production per egg.

\section{Introduction}

Since prehistoric times, plants and their extracts have been used worldwide for their medicinal properties with no adverse effect. Functional and nutraceutical foods are gaining popularity all over the globe due to their health enhancing potential. Turmeric, Latin name Curcuma longa of family Zingiberaceae, is a perennial plant having a short stem with large oblong leaves and bears ovate, pyriform or oblong rhizomes. Turmeric, a medicinal plant, is extensively used in Ayurveda, Unani and Siddha medicine as home remedy for various diseases (Ammon and Wahl, 1991). In traditional Indian medicine turmeric powder is used for the treatment of biliary disorders, anorexia, coryza, cough, diabetes, hepatic disorders, rheumatism and sinusitis (Srimal, 1997). According to Srinivasan (2007) 
turmeric has promising hypoglycemic and hypolipidemic properties. Besides, usage of this herbs for medical preparations, it can also be included in the poultry diet as feed additive to utilize their benefits to the maximum extent. Therefore, this experiment was designed to investigate the efficacy of different levels of turmeric powder supplementation on production performances of Jabalpur colour layer birds.

\section{Materials and Methods}

The study was conducted on 30 Jabalpur colour birds of 32 weeks age. Birds were kept in individual cages under standard managemental conditions during the entire period. Thirty healthy birds were randomly divided into 5 groups with 6 birds in each group. One group $\mathrm{C}$ was kept as control and other four groups, T1-T4 were kept as treatment groups. Diet of the trial groups was supplemented with turmeric powder @ 1.5, 3.0 4.5 and $6 \mathrm{~g} / \mathrm{kg}$ of diet, respectively. The basal diet consisted of $2700 \mathrm{ME} \mathrm{Kcal} / \mathrm{kg}$ of feed and $17 \%$ protein.

All the birds were weighed individually with hanging double dial balance for observing change in body weights on days $0,14,28,42$ and 56 of the experiment and daily egg production of birds was recorded on individual hen basis. Data were analysed by using CRD (Steel and Torrie, 1992).

\section{Results and Discussion}

\section{Egg production}

The mean \pm SE of egg production seen biweekly between days 0-14, 15-28, 29-42 and 43-56 of the experiment in different treatment groups of birds are presented in Table 1.The increase in egg production was 16.35, 26.63 and $39.20 \%$ for group T1, 16.95, 37.49 and $42.80 \%$ for $\mathrm{T} 2$, and $25.48,43.52$ and $53.60 \%$ for group T3 and 25.48, 43.52 and $53.60 \%$ for group T4 between 15-28, 29-42 and 43-56 days, respectively. The maximum increase in egg production was observed in groups $\mathrm{T} 2$ and T3 on day 56. The variations between days, between treatments and interactions between days $\mathrm{x}$ treatments were highly significant $(\mathrm{P}<0.01)$ (Table 2).

\section{Egg weight}

The maximum increase in egg weight was observed in the group supplemented with $4.5 \mathrm{~g}$ turmeric powder $/ \mathrm{kg}$ i.e. group T3 (14.5\%) between the interval 43 and 56 day of the treatment as compared to the value on first quarter of the experiment (Table 1). The variations between days and between treatments were highly significant $(\mathrm{P}<0.01)$, whereas, those between days $\mathrm{x}$ treatments were significant $(\mathrm{P}<0.05)$ (Table 2$)$.

\section{Body weight}

In the present study, significant $(\mathrm{P}<0.05)$ change was observed in control group $\mathrm{C}$ between days $0,14,28,42$ and 56 of the experiment. The increase in body weight was $0.24,0.36,0.50,2.20 \%$ in group $\mathrm{T} 1,0.58$, $1.34,1.44$ and $5.92 \%$ in group $\mathrm{T} 2,1.70,3.07$, 4.57 and $10.44 \%$ in group T3 and $0.09,0.69$, 2.38 and $7.12 \%$ in group T4 as compared to control group on days 14, 28, 42 and 56, respectively (Table 1 ). The maximum increase in body weight was observed in group T3 $(10.44 \%)$ on day 56.The variations between days, between treatments and between days $\mathrm{x}$ treatments were highly significant $(\mathrm{P}<0.01)$ (Table 3).

\section{Economics of production performance}

Economics of production performance of birds as a result of dietary supplementation with turmeric powder was calculated by incorporating the number of eggs produced, total feed consumed and cost of feed per $\mathrm{kg}$ for the treatment and group of birds (Table 3). 
Table.1 Production performance of different traits of Jabalpur colour birds under various treatments and duration

\begin{tabular}{|c|c|c|c|c|}
\hline & \multicolumn{4}{|c|}{ Durations } \\
\hline & 0-14 days & 15-28 days & 29-42 days & 43-56 days \\
\hline \multicolumn{5}{|c|}{ Egg production (no.) } \\
\hline $\mathrm{C}$ & $31.8^{\mathrm{a}} \pm 0.31$ & 3 and durations $2.8^{\mathrm{a}, \mathrm{b}, 1} \pm 0.31$ & $33.1^{\mathrm{b}, 1} \pm 0.48$ & $33.3^{b, 1} \pm 0.42$ \\
\hline $\mathrm{T}_{1}$ & $32.0^{\mathrm{a}, \mathrm{b}} \pm 0.32$ & $38.2^{\mathrm{b}, \mathrm{l}-2} \pm 0.49$ & $42.0^{c, 2} \pm 0.32$ & $46.4^{\mathrm{d}, 1-2} \pm 0.24$ \\
\hline $\mathrm{T}_{2}$ & $32.0^{\mathrm{a}, \mathrm{b}} \pm 0.32$ & $38.4^{\mathrm{b}, 2} \pm 0.68$ & $45.6^{c, 3} \pm 0.24$ & $47.6^{\mathrm{d}, 2} \pm 0.24$ \\
\hline $\mathrm{T}_{3}$ & $32.0^{\mathrm{a}} \pm 0.32$ & $41.2^{\mathrm{b}, 3} \pm 0.58$ & $47.6^{\mathrm{c}, 4} \pm 0.24$ & $51.2^{\mathrm{d}, 4} \pm 0.37$ \\
\hline $\mathrm{T}_{4}$ & $32.0^{\mathrm{a}} \pm 0.32$ & $40.6^{b, 3} \pm 0.87$ & $46.4^{\mathrm{c}, 3-4} \pm 0.24$ & $49.4^{\mathrm{d}, 3} \pm 0.24$ \\
\hline \multicolumn{5}{|c|}{ Egg weight (g) } \\
\hline $\mathrm{C}$ & $40.85^{\mathrm{a}} \pm 0.20$ & $42.47^{b} \pm 0.10$ & $43.46^{c} \pm 0.22$ & $46.58^{\mathrm{d}, 2} \pm 0.39$ \\
\hline $\mathrm{T} 1$ & $41.04^{\mathrm{a}} \pm 0.27$ & $42.46^{\mathrm{b}} \pm 0.11$ & $43.61^{\mathrm{c}} \pm 0.12$ & $46.83^{\mathrm{d}, 1,2} \pm 0.30$ \\
\hline $\mathrm{T} 2$ & $40.85^{\mathrm{a}} \pm 0.27$ & $42.68^{\mathrm{b}} \pm 0.03$ & $43.71^{\mathrm{c}} \pm 0.14$ & $46.83^{\mathrm{d}, 1} \pm 0.21$ \\
\hline $\mathrm{T} 3$ & $40.71^{\mathrm{a}} \pm 0.49$ & $42.92^{\mathrm{b}} \pm 0.01$ & $43.78^{\mathrm{c}} \pm 0.27$ & $47.61^{d} \pm 0.17$ \\
\hline $\mathrm{T} 4$ & $40.78^{\mathrm{a}} \pm 0.09$ & $42.75^{b} \pm 0.03$ & $43.76^{c} \pm 0.10$ & $46.70^{\mathrm{d}, 1} \pm 0.11$ \\
\hline \multicolumn{5}{|c|}{ Body weight (g) } \\
\hline $\mathrm{C}$ & $1706.7^{\mathrm{a}} \pm 7.15$ & $1781.7^{\mathrm{b}, 2} \pm 5.43$ & $1843.3^{\mathrm{c}, 2} \pm 8.43$ & $1918.3^{\mathrm{d}, 3} \pm 8.72$ \\
\hline $\mathrm{T}_{1}$ & $1690.0^{\mathrm{a}} 4.47$ & $1786.0^{\mathrm{b}, 1,2} \pm 6.78$ & $1850.0^{\mathrm{c}, 1,2} \pm 8.94$ & $1928.0^{\mathrm{d}, 2} \pm 17.15$ \\
\hline$T_{2}$ & $1710.0^{\mathrm{a}} \pm 9.49$ & $1792.0^{\mathrm{b}, 1,2} \pm 3.74$ & $1868.0^{\mathrm{c}, 1} \pm 3.74$ & $1946.0^{\mathrm{d}, 1,2} \pm 7.48$ \\
\hline $\mathrm{T}_{3}$ & $1708.0^{\mathrm{a}} \pm 11.58$ & $1812.0^{b, 1} \pm 10.68$ & $1900.0^{c, 1} \pm 6.32$ & $2006.0^{\mathrm{d}, 1} \pm 7.48$ \\
\hline $\mathrm{T}_{4}$ & $1704.0^{\mathrm{a}} \pm 5.10$ & $1780.0^{\mathrm{b}, 2} \pm 20.25$ & $1856.0^{c, 1} \pm 19.65$ & $1964.0^{\mathrm{d}, 1,2} \pm 7.48$ \\
\hline
\end{tabular}

Mean \pm SE of egg production, alphabets and numbers in superscripts vary significantly $(\mathrm{P}<0.05)$ in a row or in a column, respectively.

Table.2 Analysis of variance for different production traits studied in Jabalpur colour birds

\begin{tabular}{|l|l|c|c|c|}
\hline Trait name & Source of variation & DF & MS & F- value \\
\hline Egg production & Between days & 4 & 399.35 & $498.14^{* *}$ \\
\cline { 2 - 5 } & Between treatments & 3 & 1070.61 & $1335.48^{* *}$ \\
\cline { 2 - 5 } & Between days x treatments & 12 & 58.71 & $73.24^{* *}$ \\
\cline { 2 - 5 } & Error & 100 & 0.80 & \\
\hline \multirow{3}{*}{ Eg weight } & Between days & 4 & 0.98 & $4.04^{* *}$ \\
\cline { 2 - 5 } & Between treatments & 3 & 178.20 & $736.53^{* *}$ \\
\cline { 2 - 5 } & Between days x treatments & 12 & 0.48 & $2.00^{*}$ \\
\cline { 2 - 5 } & Error & 100 & 0.24 & \\
\hline \multirow{3}{*}{ weight } & Between days & 4 & 23822.67 & $40.51^{* *}$ \\
\cline { 2 - 5 } & Between treatments & 16 & 658352.67 & $1119.39^{* *}$ \\
\cline { 2 - 5 } & Between days x treatments & 125 & 588.13 & \\
\cline { 2 - 5 } & Error & & & \\
\hline
\end{tabular}

* Significant $(\mathrm{P}<0.05)$

** Highly significant $(\mathrm{P} \leq 0.01)$. 
Table.3 Economics of production performance of Jabalpur colour birds

\begin{tabular}{|c|c|c|c|c|c|c|c|}
\hline $\mathbf{T}$ & $\mathbf{C}$ & $\mathbf{F}$ & $\mathbf{T C}$ & $\mathbf{E P}$ & $\mathbf{C 1}$ & $\mathbf{I}_{\mathbf{1}}$ & $\mathbf{I}_{\mathbf{2}}$ \\
\hline $\mathbf{C}$ & 17.00 & 118.90 & 679.15 & 130 & 5.22 & - & 4.71 \\
\hline $\mathbf{T}_{\mathbf{1}}$ & 17.20 & 118.04 & 682.17 & 158 & 4.31 & 21.54 & 45.00 \\
\hline $\mathbf{T}_{\mathbf{2}}$ & 17.40 & 119.50 & 698.64 & 162 & 4.31 & 24.60 & 48.75 \\
\hline $\mathbf{T}_{\mathbf{3}}$ & 17.60 & 120.09 & 710.16 & 171 & 4.15 & 31.54 & 60.00 \\
\hline $\mathbf{T}_{\mathbf{4}}$ & 17.80 & 119.22 & 713.03 & 167 & 4.26 & 28.46 & 54.37 \\
\hline
\end{tabular}

$\mathrm{T}=$ treatment, $\mathrm{C}=\mathrm{Cost} / \mathrm{kg}$ feed, $\mathrm{F}=$ Feed consumed $/$ days $(\mathrm{g}), \mathrm{TC}=$ Total cost of feed consumed, $\mathrm{EP}=\mathrm{Egg}$ production, $\mathrm{C} 1$ = Cost of egg production of one egg, $\mathrm{I}_{1}=$ percentage increase in egg production w.r.t. their respective control, $\mathrm{I}_{2}=$ percentage increase in egg production w.r.t. treatment effect

Results indicated that in case of turmeric powder supplementations the feed consumption increased by $1.73 \%$ as the concentration of turmeric was increased from $1.5 \mathrm{~g} / \mathrm{kg}$ to $6.0 \mathrm{~g} / \mathrm{kg}$ of feed. Results indicated that the addition of $4.5 \mathrm{~g}$ turmeric powder/ $\mathrm{kg}$ feed improved the performance of production of birds by $53.60 \%$ as compared to the initial value of egg production during days 0 and 14 . This treatment was also found to decrease egg cholesterol and total lipids by about $35.00 \%$ in group T3 on day 56 of the treatment. Initially the cost of feed for the production of one egg was Rs. 5.22 in case of control group whereas this cost was far less i.e. Rs. 4.15 per egg in case of group T3 (4.5g turmeric powder/ $\mathrm{kg}$ feed) because of increase in egg production on turmeric supplementation in the birds feed.

The weight of the birds increased in all the treatments on days $14,28,42$ and 56 when compared with day 0 including control group. The variations between days, between treatments and between days $\mathrm{x}$ treatments were highly significant $(\mathrm{P}<0.01)$. The maximum increase in body weight was observed in group T3 (10.44\%) on day 56. Kumari et al., (2007) fed 3 days old Vancob broiler chicken mixed with turmeric powder (@ $1 \mathrm{~g} / \mathrm{kg}$ ) for 42 days and reported a better growth rate, feed consumption and feed conversion efficiency in the treated group. Al-Kassie et al., (2011) fed 300 (Arbor-Acres) day old broiler chicks diets supplemented with a mixture of cumin $(C$. cyminum) and turmeric (C. longa) @ 0.25\%, $0.50 \%, 0.75 \%$ and $1 \%$ for six weeks. Results revealed that the inclusion of cumin and turmeric mixture at levels of $0.75 \%$ and $1 \%$ in the diets improved body weight gain, feed intake and feed conversion ratio. It was concluded that the use of mixture containing cumin $($ C. cyminum $)$ and turmeric $(C$. longa $)$ as feed additive at levels $0.75 \%$ and $1 \%$ enhanced the overall performance of broiler chicks. Kumar et al., (2005) observed a significant (P < $0.05)$ increase in weight gain in broiler chickens fed with turmeric $(1 \mathrm{~g} / \mathrm{kg}$ of diet) over those of the control group. In the present study the variations between days, between treatments and between days $\mathrm{x}$ treatments were highly significant $(\mathrm{P}<0.01)$. The maximum increase in egg production was observed in group T3 (53.60\%) on day 56. Nadia et al., (2008) found that addition of herbs like thyme, rosemary, oregano and $\mathrm{C}$. longa as natural antioxidants during the laying period could improve the production performance especially at $1.0 \%$ thyme, rosemary, oregano or $0.5 \%$ C. longa increased egg production, egg mass and improved feed conversion. Addition of $1.0 \% C$. longa increased numerically values of shell weight and egg shape index. In the present study the variations between days $\mathrm{x}$ treatments were significant $(\mathrm{P}<0.05)$ whereas those between days and between treatments were highly significant. The maximum increase in egg weight was observed in the group supplemented with $4.5 \mathrm{~g}$ turmeric powder $/ \mathrm{kg}$ i.e. group T3 $(2.21 \%)$, as compared to the control group on day 56 of the treatment. Nadia 
et al., (2008) found that addition of herbs like thyme, rosemary, oregano and $C$. longa as natural antioxidants during the laying period could improve the production performance especially at $1.0 \%$ thyme, rosemary, oregano or $0.5 \%$ C. longa increased egg production, egg mass and improved feed conversion. Addition of $1.0 \%$ C. longa increased numerically values of shell weight and egg shape index. This treatment increased percentage of yolk weight and improved yolk colour by $10.87 \%$ and $15.52 \%$, respectively as compared to the control group. Production performance was improved as a result of turmeric powder supplementation in the diet by about $50 \%$ in terms of egg production. Turmeric supplementation also affected the cost of production of one egg. Cost of Rs. 5.22 per egg prior to experimentation fell to Rs. 4.15 per egg because of enhanced egg production.

In conclusion, dietary turmeric supplementation was effective in improving laying performance and internal egg qualities. Turmeric powder can be also used as a feed additive for the production of value-enhanced eggs production with increased body weight hence reducing cost of feed for production of one egg.

\section{Acknowledgement}

Authors are thankful to the Dean, College of Veterinary Science and Animal Husbandry, Jabalpur, for providing necessary facilities to carry out this research.

\section{Statement of ethical rights}

Authors declare that prior to the start of experiment all necessary ethical permissions were taken from Institute Animal Ethics Committee, College of Veterinary Science \& A.H., Jabalpur.

\section{How to cite this article:}

Shweta Singh Chauhan, D.D. Caeser, J. Shakkarpude, Kush Shrivastava, Mendi Ali Khan and Aditya Mishra. 2018. Effect of Turmeric Supplementation on Production Performance of Adult Laying Birds. Int.J.Curr.Microbiol.App.Sci. 7(08): 840-844.

doi: https://doi.org/10.20546/ijcmas.2018.708.094

\section{References}

Al-Kassie, G., A.M., A. M. Mohseen and AbdAL-Jalee, R.A. 2011. Modification of Productive Performance and Physiological Aspects of Broilers on the Addition of a Mixture of Cumin and Turmeric to the Diet. Research Opinion Animal Veterinary Science. 1(1): 31-34.

Al-Sultan, S.I., 2003. The Effect of Curcuma Longa (Turmeric) on Overall Performance of Broiler Chickens. International Journal of Poultry Science. 3: 333-336.

Ammon, H. P. T., and Wahl M. A. 1991. Pharmacology of Curcuma longa. Planta Medica. 57:1-7.

Kumar, M., R. S. Chaudhary and Vaishnav J.K. 2005. Effect of Supplemental Prebiotic and Turmeric in the Diet on the Performance of Broiler Chicks During Summer. Indian Journal of Poultry Science. 40: 137-141.

Kumari, P., M. K. Gupta, R. K. Ranjan, K. K. Singh and Yadava R. 2007. Curcuma Longa as Feed Additive in Broiler Birds and its Patho- Physiological Effects. Indian Journal of Experimental Biology. 45: 272-277.

Nadia, R., L. R. A. Hassan, E. M. Qota and Fayek H. M. 2008. Effect of Natural Antioxidant on Oxidative Stability of Eggs and Productive and Reproductive Performance of Laying Hens. International Journal of Poultry Science. 7 (2): 134-150.

Srimal, R. C. 1997. Turmeric: A Brief Review of Medicinal Properties. Fitoterapia LXVIII. No. 6: 483-493.

Srinivasan., K. 2007. Spices as Influencers of Body Metabolism: An Overview of Three Decades of Research. Food Research International. 38:77-86.

Steel, R. G. D., and Torrie J. H. 1992. Principles and Procedures of Statistics: A Biometrical Approach. McGraw Hill, New York. 